\title{
Special issue on construction aggregates
}

\author{
Richard Prikryl ${ }^{1}$ \\ Published online: 22 November 2021 \\ (c) Springer-Verlag GmbH Germany, part of Springer Nature 2021
}

\section{Introduction}

Construction aggregates deserve special attention not only as the most voluminous mineral raw material extracted and utilised by humans, but also as one of the essential materials supporting development and functioning of the basic infrastructure of our civilization. To extend our understanding of the role of constructional geomaterials (including aggregates) and on how geologists can contribute to their study, series of conferences focused on constructional geomaterials including aggregates since 2001 (Table 1). Since the very beginning, organizers of these scientific meetings tried to preserve several characteristic features: informal spirit balanced with high scientific standard, open space to any nationality and level of scientific carrier (students, earlycarrier scientists have been welcome all the time), and trial to provide space for high-quality publications submitted to fair peer-review process in well-established scientific journal or book series under the most important publishing houses. Besides this, all the work in the organization of meetings or conference sessions was (and is) kept strictly informal and volunteer, to promote its enthusiastic character.

During the past 20 years, these international scientific gatherings allowed to exchange novel ideas between thousands of scientists worldwide. Along with these fruitful meetings, 6 journal special issues (Table 2) covering specific topics of constructional geomaterials have been released (including the current one). Besides these journal volumes, another 7 books under the editorial role of the author of this contribution were realised (Table 3 ), and another book is under preparation.

The current special issue of the Bulletin of Engineering Geology and the Environment has a very special position and focus compared to the previous ones. In reality, it is the

Richard Přikryl

richard.prikryl@natur.cuni.cz

1 Institute of Geochemistry, Mineralogy and Mineral Resources, Faculty of Science, Charles University in Prague, Albertov 6, 12843 Prague, Czech Republic first special issue of our informal initiative on Constructional GeoMaterials focusing only on aggregates in construction. This special issue contains 10 papers, most of which have been presented during the meetings since 2016. All the papers address important topics related to the current study of aggregates in construction.

\section{Aggregates in construction}

\section{General issues}

Aggregates are essential granular materials used in civil engineering; at the same time they make the most voluminous material extracted by humans from the lithosphere (Prrikryl 2021). The role of aggregates in modern society desires much more appreciation also from the scientific community (Přikryl 2021). Although civil engineers rely on certain standardized properties of aggregates, these are tightly related to the genesis of source rocks, their mineralogical and geochemical composition, rock fabric and postgenetic development, i.e. properties which are sometimes omitted during the interpretation of their properties. As extraction of aggregates is linked to some environmental problems, sustainability of the whole aggregate industry is questioned as well (Přikryl 2021).

Standardization of the test methods for various aggregates used in diverse application is a major issue raised during recent decades. However, application of international standards - such as European ones - can have some limitation along with numerous advantages. Disability to cover all differences resulting from local/regional/national conditions can make serious problems when trying to use some specific types of aggregates. This question has been highlighted in the current special issue by Fladvad and Ulvik (2019) by discussing the issue related to sampling, testing and usage of large-size aggregates (i.e. above $90 \mathrm{~mm}$ in diameter). Fladvad and Ulvik's (2019) argument is that some of the conventionally advised test procedures are not adoptable for these large-size aggregates which implies application of 


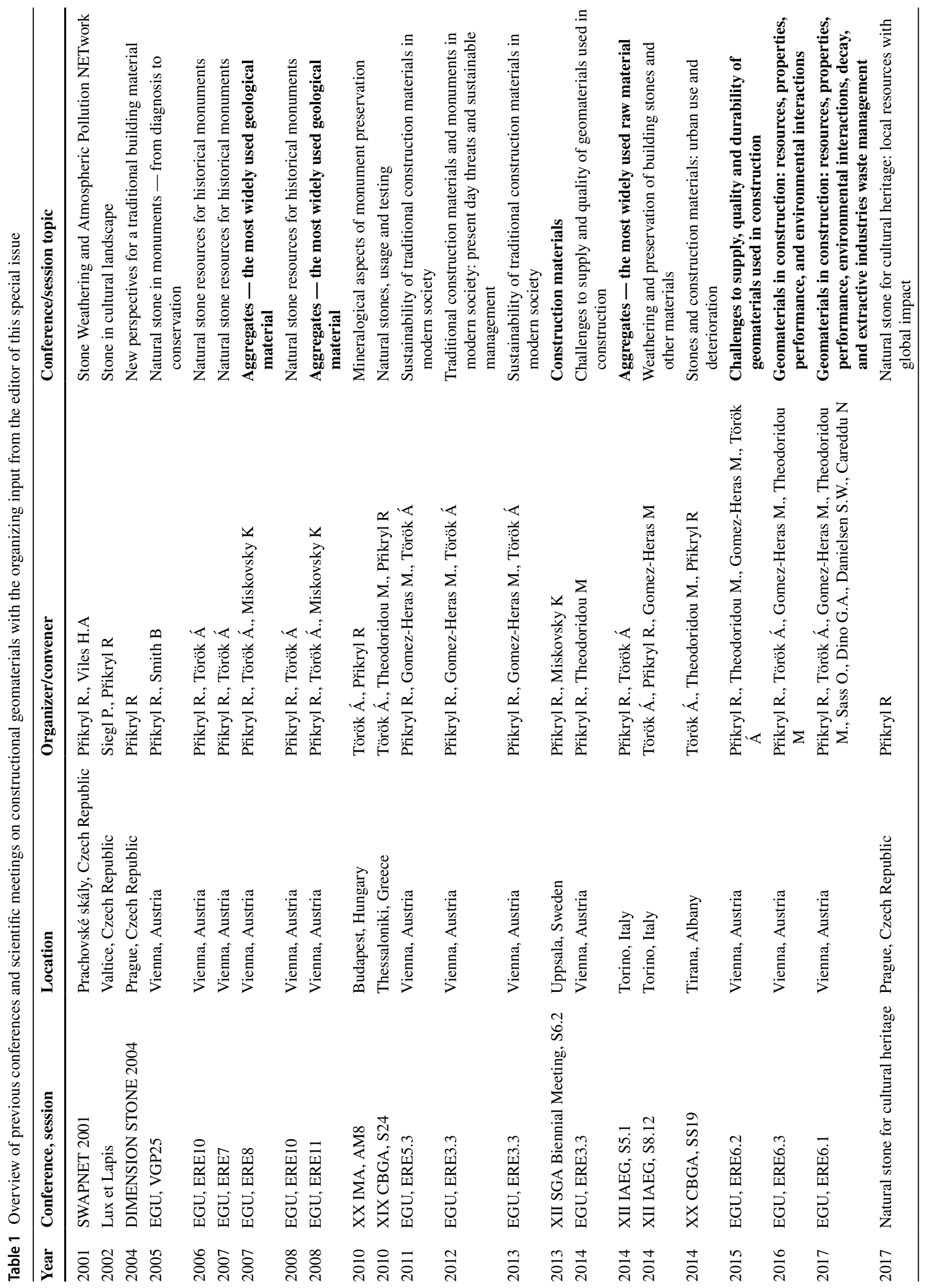


methodological creativity combined with specific national knowledge, such as Norwegian in this case.

\section{Mechanical performance of aggregates}

Resistance to external loads of various natures is one of the fundamental desirable properties of aggregates either in unbound or in bound states. As shown in the extensive review by Přikryl (2021), several authors came to rather variable views on mutual relationship between rock mechanical properties (mostly compressive strength) and their technological-mechanical performance (expressed by various empirical tests such as Los Angeles attrition value, Aggregate Crushing Value, Aggregate Impact Value, and/ or micro-Deval test). Czinder and Török (2020) tested the relationship between compressive strength and micro-Deval value for various andesite rocks, concluding that sound exponential correlation exists for these variables.

The mechanical behaviour of aggregates is significantly influenced by their shape. In the case of coarser particles, CT scanning of gravel-sized particles allows for better recognition of their role and movement during triaxial testing (Zhang et al. 2019).

\section{Soundness of aggregates and their composition}

About half of the aggregates are used in bound state, mostly in hydraulic cement concrete (Prrikryl 2021). As the aggregates make up to $80 \mathrm{vol} \%$ in concrete, they significantly influence its properties including durability. As shown on the example of crushed stone fine aggregates from ophiolitic formations in Cyprus (Fournari et al. 2021), rock mineralogical composition together with its postgenetic history and physical properties significantly influences the quality of resulting concrete and/or mortar. Detailed mineralogicalpetrographical investigation thus should make the basis of the evaluation of any aggregate (Fournari et al. 2021).

Soundness of aggregate source rock is conventionally evaluated by a series of test methods including resistance to slat crystallization and/or technological-mechanical performance. Czinder and Török (2019) examined the behaviour of andesite aggregate in a prolonged salt crystallization test and influence of related microstructural changes on technological-mechanical performance. Based on their results, an increasing number of salt crystallization tests do not necessarily deteriorate the mechanical response of the tested aggregates (Czinder and Török 2019).

\section{Extending knowledge on alkali-silica reactivity}

Sound understanding of mineralogical and geochemical factors on the development of alkali-silica reaction is one of the most effective approaches on how to mitigate its occurrence 
Table 2 Overview of journal special issues and edited book publications based on previous conferences and scientific meetings on constructional geomaterials

\begin{tabular}{|c|c|c|c|}
\hline Year & Journal & Topic of special issue & Special issue guest editors \\
\hline 2010 & Engineering Geology & Natural stones for historical monuments, testing, durability and provenance & Török Á., Přikryl R \\
\hline 2017 & $\begin{array}{l}\text { Bulletin of Engineering } \\
\text { Geology and the } \\
\text { Environment }\end{array}$ & Challenges to supply and quality of geomaterials used in construction & Přikryl R \\
\hline 2017 & Environmental Earth Science & $\begin{array}{l}\text { Geomaterial used as construction raw materials and their environmental } \\
\text { interactions }\end{array}$ & $\begin{array}{l}\text { Přikryl R., Török Á., } \\
\text { Theodoridou M., } \\
\text { Gomez-Heras M }\end{array}$ \\
\hline 2018 & Resource Policy & Raw materials associated with extractive industry & $\begin{array}{l}\text { Careddu N., Dino G. A., } \\
\text { Danielsen S. W., Přikryl } \\
\text { R }\end{array}$ \\
\hline 2021 & Minerals & Minerals and other phases in Constructional Geomaterials & Přikryl R., Török Á \\
\hline 2021 & $\begin{array}{l}\text { Bulletin of Engineering } \\
\text { Geology and the } \\
\text { Environment }\end{array}$ & Aggregates (current issue) & Přikryl R \\
\hline
\end{tabular}

in concrete. Medeiros et al. (2020) have shown how modern techniques such as electron probe microscope can help in the discrimination of reactive/non-reactive volcanic rocks from precise measurement of volcanic glass composition.

Laboratory testing of the aggregate's alkali-silica reactivity by various accelerated methods became the most popular approach on the evaluation of rock susceptibility to this deleterious chemical reaction. Recently, rapid to ultrarapid test methods by using mortar bars subjected to high temperatures of about $80{ }^{\circ} \mathrm{C}$ are replaced by a slower concrete prism test at lower temperatures of 38 or $60^{\circ} \mathrm{C}$ (Marfil et al. 2019). Mutual correlation of likelihood of alkali-silica reactivity obtained by these methods is rather controversial; however, a slower concrete prism test at lower temperature proves better results and sound correlation to the content of microcrystalline silica (Marfil et al. 2019).
Moreover, interpretation of physical changes of concrete test specimens related to development of alkalisilica-reactivity in laboratory conditions deserves more attention than just simple measurement of length changes. Recording of changes in dynamic elastic properties seems to be a very effective non-destructive measure of degree of damage and tightly correlates with length changes (Lokajíček et al. 2021).

Despite numerous difficulties related to realistic replication of alkali-silica reactivity in laboratory conditions, some approaches such as microwave radiation allow for its rapid occurrence as shown by Doria and Barreto (2021). Development of rapid activation of alkali-silica reaction is extremely important specifically due to the search for appropriate methods of its mitigation (Doria and Barreto 2021).

Table 3 Overview of edited book publications based on previous conferences and scientific meetings on constructional geomaterials

\begin{tabular}{|c|c|c|c|}
\hline Year & Publisher & Book title & Book guest editors \\
\hline 2002 & Karolinum & Understanding and managing stone decay & Přrikryl R., Viles H \\
\hline 2004 & A.A. Balkema Publishers & $\begin{array}{l}\text { Dimension stone. New perspectives for a } \\
\text { traditional building material }\end{array}$ & Přikryl R \\
\hline 2017 & Karolinum & $\begin{array}{l}\text { Architectural and sculptural stone in cultural } \\
\text { landscape }\end{array}$ & Přikryl R., Siegl P \\
\hline 2007 & $\begin{array}{l}\text { Geological Society, London, Special } \\
\text { Publications }\end{array}$ & $\begin{array}{l}\text { Building Stone Decay: From Diagnosis to } \\
\text { Conservation }\end{array}$ & Přikryl R., Smith B. J \\
\hline 2010 & Springer & $\begin{array}{l}\text { Materials, Technologies and Practice in Historic } \\
\text { Heritage Structures }\end{array}$ & Boştenaru M., Přikryl R., Török Á \\
\hline 2010 & $\begin{array}{l}\text { Geological Society, London, Special } \\
\text { Publications }\end{array}$ & Natural stone resources for historical monuments & Přikryl R \\
\hline 2016 & $\begin{array}{l}\text { Geological Society, London, Special } \\
\text { Publications }\end{array}$ & $\begin{array}{l}\text { Sustainable use of traditional geomaterials in } \\
\text { construction practice }\end{array}$ & $\begin{array}{l}\text { Přikryl R., Török Á., Gómez-Heras } \\
\text { M., Miskovsky K., Theodoridou M }\end{array}$ \\
\hline
\end{tabular}


Acknowledgements First, the author of this foreword and organizer of the special issue must express his sincere thanks to the editors-in-chief of the Bulletin of Engineering Geology and the Environment for their long-term support and help with the preparation of this special issue. Thanks are also due to the authors for their willingness to publish their research in the current special issue, and also for their patience with the prolonged preparation of the special issue, mostly caused by almost 2 -years of lasting difficulties associated with the COVID pandemic. Last, but not the least, Richard Prrikryl's role as an organizer or convenor of the mentioned conference and as guest editor of the current special issue would not be possible without the kind financial support from the Czech Science Foundation research projects to R. Přikryl, specifically projects $18-08826 \mathrm{~S}$ and $21-26542 \mathrm{~S}$.

\section{References}

Czinder B, Török Á (2019) Effects of long-term magnesium sulfate crystallisation tests on abrasion and durability of andesite aggregates. Bull Eng Geol Environ. https://doi.org/10.1007/ s10064-019-01600-4

Czinder B, Török Á (2020) Strength and abrasive properties of andesite: relationships between strength parameters measured on cylindrical test specimens and micro-Deval values - a tool for durability assessment. Bull Eng Geol Environ. https://doi.org/10. 1007/s10064-020-01983-9

Doria MR, Barreto LS (2021) Activation of alkali-silica reactivity under microwave action and passivation of reactive aggregate by treatment with lithium nitrate. Bull Eng Geol Environ. https://doi. org/10.1007/s10064-021-02141-5

Fladvad M, Ulvik A (2019) Large-size aggregates for road constructiona review of standard specifications and test methods. Bull Eng Geol Environ. https://doi.org/10.1007/s10064-019-01683-z

Fournari R, Ioannou I, Rigopoulos I (2021) The influence of ophiolitic crushed fine aggregate properties on the performance of cement mortars. Bull Eng Geol Environ. https://doi.org/10.1007/ s10064-021-02195-5

Lokajíček T, Petružálek M, Svitek T, Kuchařová A, Šachlová Š, Přikryl R (2021) Dynamic elastic properties of hardened experimental mortar bars affected by accelerated alkali-silica reactivity test: a laboratory approach. Bull Eng Geol Environ. https://doi.org/10. 1007/s10064-021-02251-0

Marfil PP, Locati F, Marfil S, Falcone D (2019) Assessment of the potential alkali-reactivity of slow-reacting aggregates from the province of Buenos Aires, Argentina. Bull Eng Geol Environ. https://doi.org/10.1007/s10064-019-01551-w

Medeiros S, Fernandes I, Fournier B, Nunes JC, Ramos V (2020) Hawaiian and Azorean volcanic aggregates: a preliminary study of the potential alkali-silica reaction. Bull Eng Geol Environ. https:// doi.org/10.1007/s10064-019-01702-z

Přikryl R (2021) Geomaterials as construction aggregates: a state-ofthe-art. Bull Eng Geol Environ

Zhang D, Ji T, Zheng B, Wang G, Shi B (2019) Analysis method for spatial movement of gravels in mixed soil during triaxial testing. Bull Eng Geol Environ. https://doi.org/10.1007/ s10064-019-01573-4 